\title{
Isolation of Nine Microorganisms from Rotten Dioscorea rotundata (White Yam) and Antimicrobial Sensitivity Test with Five Plant Extracts
}

\author{
Dooshima Shiriki', Simon Terver Ubwa², Tseaa Shambe ${ }^{2 *}$ \\ ${ }^{1}$ Department of Biological Sciences, Benue State University, Makurdi, Nigeria \\ ${ }^{2}$ Department of Chemistry, Benue State University, Makurdi, Nigeria \\ Email: tshambe@bsum.edu.ng
}

Received 11 May 2015; accepted 5 July 2015; published 8 July 2015

Copyright (C) 2015 by authors and Scientific Research Publishing Inc.

This work is licensed under the Creative Commons Attribution International License (CC BY).

http://creativecommons.org/licenses/by/4.0/

(c) (i) Open Access

\begin{abstract}
Five yam tuber varieties were investigated for microorganisms that cause yam tuber rot from five local government areas of Benue State, Nigeria, between the months of March 2014 to March 2015. Five fungi species: Aspergillus niger, Rhizopus stolonifera, Botryodiplodia theobromae, Fusarium oxysporum, Penicillium marnessei and four bacteria species: Serratia marcescens, Erwinia carotovora, Klebsiella oxytoca and Pseudomonas aeruginosa were consistently isolated. Pathogenicity test carried out confirmed these organisms as the pathological agent of the rot. Antimicrobial activity of five plant aqueous extracts: Terminalia catapa (common name fruit), Passiflora edulis (passion fruit), Daniella oliveri (Chiha-Tiv), Ceiba pentandra (Vambe-Tiv), Jatropha tanjorensis (Catholic plant) was carried out on the isolated microorganims and they showed varing degrees of inhibition, the aqueous extract from Passiflora edulis, Ceiba pentandra and Jatropha tanjorensis were able to inhibit all the fungi completely.
\end{abstract}

\section{Keywords}

Yam Rot, Bacteria, Fungi, Plant Extract, Inhibition

\section{Introduction}

Dioscorea rotundata, the white yam belongs to the family Dioscoreaceae; they are perennial herbaceous vines

*Corresponding author.

How to cite this paper: Shiriki, D., Ubwa, S.T. and Shambe, T. (2015) Isolation of Nine Microorganisms from Rotten Dioscorea rotundata (White Yam) and Antimicrobial Sensitivity Test with Five Plant Extracts. Food and Nutrition Sciences, 6, 825835. http://dx.doi.org/10.4236/fns.2015.610086 
cultivated mainly for the consumption of their starchy tubers in West Africa, Asia, Latin America, the Caribbean and Oceania [1] [2]. Nigeria, in West Africa, is the major producer of the white yam and the major yam producing states in Nigeria are Benue, Taraba, Adamawa, Nassarawa, Ekiti, Kwara, Kaduna, Ogun, Oyo, Delta, Plateau, Edo, Cross River, Imo, Ondo, and Osun [3]-[6].

Yam crop is harvested once a year (November to December), even though new yam tubers appear in June in some places and are consumed with festivities [2] [7]. Yam tubers are stored using traditional methods [8] and are difficult to preserve and store over extended periods of time. In storage, heat or high temperature causes rot in the stored yam tuber [2] [7]. This can be prevented by providing adequate ventilation in the store house or storage area. Yam tubers sprout during storage using up the reserve carbohydrates meant for humans; this can be arrested by the use of gamma irradiation [4] or by hand removal of the sprout.

Nematodes attack yam tubers on the farm causing wounds which may serve as entry point for rot causing microorganisms [9]-[11] but this can be prevented by the use of chemicals [4].

Rodents attack yam tubers causing wounds [10] [11]. In storage this can be prevented by screening the store house or storage area with wire mesh.

The largest postharvest losses in yams result from microbial attacks [8]. The yam tuber naturally has a periderm (outer cover) which microorganisms can not easily penetrate. It is easily wounded by rodents, nematodes and man during weeding, harvesting and postharvest handling. Such wounds facilitate the penetration and development of rot microorganisms [9] [10]. Microbial storage disease of yam tubers can be categorised into three (3), based on symptoms and the causal agents [12]. These are the dry rot, the soft rot and the wet or watery rot. In the dry rot, the infected tissues become hard and dry with varing coloration depending on the microorganism involved. It is caused by the Fusarium species and the species responsible for it are Fusarium oxysporum, Fusarium moniliforme and Fusarium solani [12] [13]. Soft rot cause the infected tissues to become soft ramified by the fungal mycelium and turn brown and sometimes wet due to a rapid collapse of the cell walls inducing pinkish with yellowish border on the affected tissues. Fungi associated with soft rot include Armillariella mellea, Mucor circinelloides, Rhizoctonia solani and Rhizopus spp. [6] [12] [14]. The wet or watery rot of yam tuber is characterized by the oozing of whitish fluid from the tissues when pressed. It is usually associated with Erwinia carotovora, a bacterium [12].

Pathogernic fungi of the yam tuber include Aspergillus flavus, Aspergillus niger, Aspergillus tamari, Botryodiplodia theobromae, Cladosporium herbarum, Fusarion oxysporum, Fusarium solani, Penicillium chrysogenom, Penicillium oxalicum, Rhizopus nodosus, Rhizoctonia spp. and Trichoderma viride [15] [16].

Literature review on antimicrobial activity of plants shows that many plant aqueous extracts are extensively used by natives and international community for treating diseases [17]-[21]. In case of microorganisms responsible for causing yam rot, no literature was cited for the use of aqueous extracts for inhibition of microorganisms by the above plants. The plants used in this study are commonly used for human consumption and there are no literature reports indicating toxicity of the plants. This study is geared at determining the nature of the fungal and bacteria species associated with tuber rot of the yam samples assessed and the use of plant extracts from edible plants, for strategic control measures which may be recommended for farmers to adapt for its application on the tubers before storage.

\section{Materials and Methods}

\subsection{Materials}

Sixty tubers of Dioscorea rotundata, the white yam varieties, Amula, Ogoja, Hembamkwase and Gbongu (15 pieces of each variety) showing visible signs of rot and 44 healthy ones were purchased from markets in Ukum, Katsina Ala, Logo, Vandeikya and Guma, Local Government Areas of Benue State between the months of March and May, 2014, and the whole work lasted up to March, 2015.

The yam samples were properly labelled at collection points, packaged in cellophane bags and transported to the microbiology laboratory of the Benue State University for analysis.

Standard analysis methods [15] [16] [22]-[25] were employed to culture, isolate, identify and evaluate antimicrobial sensitivity of the rot microorganisms using the plant extracts.

The culture media;Potatoe Dextrose Agar, Nutrient Agar, Nutrient broth, MacConkey Agar, Triple Sugar Iron Agar (TSIA), Simon Citerate Agar were purchased from TITAN BIOTECH TM, GUANGDONGHUAKAI MICROBIAL SCI.\&TECH.CO.LTD, SCHARLAU-SPAIN, BIOTEC LABORATORIES LTD, UK respectively. 
The reagents used for the work, Grams staining reagents (crystal violet, lugol's iodine, absolute alcohol, safranin); catalase reagent (hydrogen peroxide); Covacs reagents; oxidase reagent; Sodium hypochlorite, were purchased from BDH CHEMICALS ENGLAND; M\&B, LABORATORY REAGENT, ENGLAND; Reckitt Benckiser, Nigeria respectively were used.

The plants, Terminalia catapa (fruit plant-leaves), Passiflora edulis (passion fruit-fruit peels), Daniella oliveri (Chiha-Tiv-leaves), Ceiba pentandra (Vambe-Tiv-leaves) and Jatropha tanjorensis (Catholic plantleaves) were collected at Tse-Abu Village, off km4 Gboko road, Makurdi and used for the antimicrobial sensitivity test.

\subsection{Microbial Isolation}

\subsubsection{Sample Preparation}

The method of [15] was used with some modifications. The yams were peeled to expose the rot tissues. Using a sharp knife and forcept, an estimated $5 \mathrm{~mm}$ pieces were cut and surface sterilised by placing in a $10 \%$ sodium hypochlorite solution for 2 minutes. The pieces were then removed,washed and rinsed by placing them in 3 changes of sterile distilled water for 3 minutes at each wash. They were placed on sterile Whatman No. 1 filter paper and put to dry in a laminar air flow cabinet for 5 minutes.

\subsubsection{Media Preparation}

Potatoe dextrose agar + chloramphenicol, Nutrient Agar and Macconkey Agar were prepared according to manufacturer directions; $40.0 \mathrm{~g} / \mathrm{L}, 38.0 \mathrm{~g} / \mathrm{L}$ and $58.0 \mathrm{~g} / \mathrm{L}$ (weight of powdered media/volume of distilled water) respectively; the Nutreint broth, Simon citerate agar,and TSIA were prepared in in 1liter bulk according to manufacturers direction $18.0 \mathrm{~g} / \mathrm{L}, 24.0 \mathrm{~g} / \mathrm{L}, 63.3 \mathrm{~g} / \mathrm{L}$ respectively and boiled to dissolve ingredients completely, then dispensed $20.0 \mathrm{~mL}$ portions into test tubes, and all media were autoclaved at $121^{\circ} \mathrm{C}$ and $15 p s i$ for $15 \mathrm{minutes,in}$ an autoclave (Gallenkamp-England); the media for the plate culture were allowed to cool to $45^{\circ} \mathrm{C}$ and were aseptically poured into sterile petri dishes and allowed to set. The media were subjected to sterility testing by incubating them at $37^{\circ} \mathrm{C}$ for 24 hours and observing for absence of microbial growth.The sterile media plates were then used for the innoculations [16].

\subsubsection{Inoculation}

The method of [15] was used. The plates were labelled with the yam codes and three pieces of the prepared rot samples were aseptically lifted and seeded on the potatoe dextrose agar for fungi organisms and on nutrient agar plates for the bacteria organisms. The plates were incubated (Memmert-UE/ULE/SLE 500) at $37^{\circ} \mathrm{C}$ and observed, for 24 - 48 hours for bacteria and for up to seven days for fungi. The observed growths were subcultured for pure isolates on fresh culture plates and this step was repeated several times until pure cultures (single species of organism) were derived on the culture plate. However, several attempts to isolate a pure culture of the fungi identified to be Penicillium marnesei failed and as such other studies where the pure isolates were used did not include it.

\subsubsection{Identification}

The method of [16] was used for the various tests and examinations. The bacteria isolated were subjected to Gram staining, sugar fermentation, catalase, oxidase, motility and capsule staining tests for identification.The Gram stained slides of the organisms were viewed under a binocular digital camera microscope (Olympus, model) at $\times 100$ objective lens using immersion oil (clove-cedar wood oil). The grams reactions and the shape of the bacteria were recorded,also photo micrographs were snaped. Sugar fermentation test was carried out using Triple sugar iron agar (TSIA). Bergey’s manual of systematic bacteriology [22] was used for their identification.

The fungi isolates were mounted, few strands in Lactophenol cotton blue on a microscope slide and also viewed under a binocular digital camera microscope (Olympus)and photo micrographs were taken. Fungal identification guides [23] was employed for their identification.

\subsubsection{Optimal Growth Temperature}

The method of [16] was used. The various isolates were each innoculated and incubated at temperatures ranging from $28^{\circ} \mathrm{C}$ to $42^{\circ} \mathrm{C}$ and their growth and radial growth diameter were observed and measured. 


\subsubsection{Pathogenicity Test}

The method of [15] was used with some modifications. The healthy yam tubers were washed with clean tap water for 10 minutes and surface disinfected with $10 \%(\mathrm{v} / \mathrm{v})$ sodium hypochlorite solution for 2 minutes. They were rinsed by placing in three changes of sterile water for 3 minutes at each instance and dried on sterile plain sheets for 20 minutes in a laminar air flow cabinet. The tuber lengths were measured and divided into five segments for the fungi and four segments for the bacteria types.Other segments for all fungi; all bacteria; then all bacteria and all fungi were also measured on fresh tubers. A peel of the outer layer was made on each segement and using a sterile $7 \mathrm{~mm}$ cork borer, a hole $3 \mathrm{~mm}$ deep was made. A disc of $5 \mathrm{~mm}$ of the organisms on their growth media was removed with a sterile $5 \mathrm{~mm}$ cork borer and placed in each hole respectively. This was covered by replacing the tuber peel and sealing with masking tape. The tubers were placed in a safety chamber at room temperature for nine days. Then, tubers were tranversely cut in each inoculated segement and observations were made and recorded.

\subsubsection{Plant Extract Preparation}

The method of [24] was used with some modifications. The leavesof Terminalia catapa, Daniella oliveri, Ceiba pentandra, Jatropha tanjorensis and fruit peels of passiflora edulis were washed in clean water to remove surface dirt. They were put to dry indoor on clean plain sheets, placed on tiled laboratory work bench for two weeks. They were dried to constant weight in an oven at $40^{\circ} \mathrm{C}$ and seperately pounded in a wooden mortar and blended using a warring blender to fine powder. A $1.0 \mathrm{~g}$ each of powdered plant material was separately placed in $100 \mathrm{ml}$ volumetric flask and sterile distilled water added to the mark. It was thoroughly mixed and allowed to soak for 12 hours, then filtered using Whatman No. 1 filter paper and kept in the refrigerator for antimicrobial activity test.

\subsubsection{Plant Extract Incorporation}

The method of [25] was used. The plant extracts solution and its serial dilutions of $10^{-1}$ and $10^{-2}$ were prepared. The extract solutions were diluted to give a $10^{-1}$ and $10^{-2}$ solutions by adding $1.0 \mathrm{~mL}$ each of the plant extract stock solutions in $10.0 \mathrm{~mL}$ and $100 \mathrm{~mL}$ standard volumetric flask then making it up tomark with sterile distilled water respectively. A $1.0 \mathrm{~mL}$ of the undiluted stock and $1.0 \mathrm{~mL}$ each of the two dilutions of plant extracts were added into labelled sterile petri dishes respectively and molten nutrient Agar or potatoe dextrose agar held at $45^{\circ} \mathrm{C}$ were poured onto it and mixed properly by rotating the plates on the flat surface, the plates were allowed to set for 30 minutesthen used for antimicrobial test.

\subsubsection{Antimicrobial Sensitivity Test}

The method of [25] was used with some modifications. The various isolates were each cultured on the plant extract incorporated media plates and incubated for 24 hours (bacteria) and for up to 7 days (fungi); control for each of the isolates were carried out by seeding on media plates poured on $1 \mathrm{~mL}$ sterile distilled water, instead of the extract. The effect of the extracts on the microbial growth and survival was observed and recorded.

\section{Results and Discussion}

\subsection{Results}

Five fungi species, Aspergillus niger, Rhizopus stolonifera, Botryodiplodia theobromae, Fusarium oxysporum and Penicillium marnessei; and four bacterial species, Serratia marcescens, Erwinia carotovora, Klebsiella oxytoca and Pseudomonas aeruginosa, were isolated from the yam samples. Pure isolate of Penicillium marnessei was not obtained due to tight growth with Aspergillus niger and contamination by its spores, so further work was not done using it (Table 1).

Aspergillus niger recorded the highest incidence of occurence in all the sampled areas and yam varieties, followed by penicillium marnessei recording high occurance in the Amula and Gbongu varieties. The attack of the microorganisms on the various species of yams vary from one local government area to the other and in some cases they were completely absent. It thus appears that in the areas where they do appear, conditions are favourable for their growth. Serratia and Erwinia species showed zero occurance in the Amula varieties sampled in all the five Local government areas. Ogoja variety recorded high incidence of Serretia marcescens 
Table 1. Microorganisms isolated from white yam species.

\begin{tabular}{|c|c|c|c|c|c|}
\hline \multicolumn{2}{|c|}{ Microorganisms } & \multirow{2}{*}{$\begin{array}{c}\text { Amula } \\
+\end{array}$} & \multirow{2}{*}{$\begin{array}{c}\text { Ogoja } \\
+\end{array}$} & \multirow{2}{*}{$\begin{array}{c}\text { Hembamkwase } \\
+\end{array}$} & \multirow{2}{*}{$\begin{array}{c}\text { Gbongu } \\
+\end{array}$} \\
\hline Fungi Isolated & Aspergillus niger & & & & \\
\hline & Rhizopus stolonifera & + & + & + & + \\
\hline & Botryodiplodia theobromae & + & + & + & + \\
\hline & Fusarium oxysporum & + & + & + & + \\
\hline & Penicillium marnessei & + & + & + & + \\
\hline \multirow[t]{4}{*}{ BacteriaIsolated } & Serratia marcescens & - & + & - & + \\
\hline & Erwinia carotovora & - & + & + & + \\
\hline & Klebsiella oxytoca & + & + & + & - \\
\hline & Pseudomonas aeruginosa & + & + & + & + \\
\hline
\end{tabular}

Key: + = Present; - = Absent.

occurrence. Klebsiella and Pseudomonas species recorded mild to moderate incidence of occurence among the varieties (Table 2).

Biochemical tests carried out identified and confirmed the bacteria isolates to be Serratia marcescens, Erwinia carotovora, Klebsiella oxytoca and Pseudomas aeruginosa (Table 3).

Optimal growth temperature was recorded at $38^{\circ} \mathrm{C}$ for both the fungi and bacteria species. At $28^{\circ} \mathrm{C}$, the growth of the bacteria Pseudomonas aruginosa was very well supported, however, the fungi Aspergillus niger, Rhizopus stolonifera, Botryodiplodia theobromae, Fusarium oxysporum, andbacteria Serratia marcescens, Erwinia carotovora, and Klebsiella oxytoca, were only fairly supported at $32^{\circ} \mathrm{C}$ to $38^{\circ} \mathrm{C}$, all isolates grew very well. The growth of Aspergillus niger and Botrydiplodia theobromae were highly retarded at temperatures above $40^{\circ} \mathrm{C}$ while the growth of Rhizopus stolonifera and Fusarium oxysporum were only slightly retarded (Table 4).

Pathogenicity test using the isolates showed varying degrees of rot with different organisms. Yam varieties that did not show presence of certain isolates, however showed rot initiation on introduction of the microorganisms. The result shows that the organisms isolated were responsible for the rot (Table 5).

Antimicrobial sensitivity tests revealed antifungal and antibacterial activity of the plant extracts. Aspergillus niger showed mild activity to extracts of Terminalia catapaat undiluted (100\%) concentration and no activity in the dilutions. Passiflora edulisrecorded good sensitivity at undiluted and $10^{-1}$ concerntrations, mild sensitivity at $10^{-2}$ concentration. Daniella oliveri recorded mild sensitivity at undiluted concentration and no activity with the dilutions. Ceiba pentandra showed no activity at undiluted concentration, but rather showed mild activity at $10^{-1}$ and $10^{-2}$ concentrations. Jatropha tanjorensis extract showed mild activity in all the concentrations, [undiluted concentration (100\%), $10^{-1}$ and $10^{-2}$ concentrations] (Table 6).

Rhizopus stoloniferashowed moderate sensitivity to extract of Terminalia catapa at undiluted concentration, mild sensitivity at $10^{-1}$ and $10^{-2}$ concentrations. Passiflora edulis extract recorded high sensitivity at undiluted and $10^{-1}$ concentrations, mild sensitivity at $10^{-2}$ concentration. Daniella oliveri and Ceiba pentandra showed no activity in all the concentrations. Jatropha tanjorensis extracts showed good activity at undiluted concentration and mild activity at $10^{-1}$ concentration,no activity at $10^{-2}$ concentration (Table 6).

Botryodiplodia theobromaeshowed no sensitivity. Passiflora edulis extract showed good sensitivity in all the concentrations. Daniella oliveri extract showed mild activity at undiluted concentration only. Ceiba pentandra and Jatropha tanjorensis showed no activity in all the concentrations (Table 6).

Fusarium oxysporum showed mild sensitivty with Terminalia catapa extract in all the concentrations (undiluted concentration (100\%), $10^{-1}$, and $10^{-2}$ ). Passiflora edulis extract showed good sensitivity at $100 \%$ concentration and moderate activity in $10^{-1}$ and $10^{-2}$ concentrations. Daniella oliveri extract recorded mild sensitivity at $100 \%$ and $10^{-1}$ concentrations, moderate sensitivity at $10^{-2}$ concentration. Ceiba pentandr are corded good sensitivity at undiluted and $10^{-1}$ concentrations and mild sensitivity at $10^{-2}$ concentration. Jatropha tanjorensis showed good sensitivity at undiluted concentration, moderate sensitivity at $10^{-1}$ concentration and mild sensitivity at $10^{-2}$ (Table 6). 
Table 2. Incidence of microbial isolation/sampling area.

\begin{tabular}{|c|c|c|c|c|c|c|c|c|c|}
\hline \multirow{2}{*}{$\begin{array}{l}\text { Yam Variety/ } \\
\text { Sample Area }\end{array}$} & \multicolumn{5}{|c|}{ Fungi Isolated } & \multicolumn{4}{|c|}{ Bacteria Isolated } \\
\hline & $\begin{array}{l}\text { Aspergillus } \\
\text { niger }\end{array}$ & $\begin{array}{l}\text { Rhizopus } \\
\text { stolonifera }\end{array}$ & $\begin{array}{c}\text { Botryodiplodia } \\
\text { theobromae }\end{array}$ & $\begin{array}{l}\text { Fusarium } \\
\text { oxysporum }\end{array}$ & $\begin{array}{c}\text { Penicillium } \\
\text { marnessei }\end{array}$ & $\begin{array}{c}\text { Serratia } \\
\text { marcescens }\end{array}$ & $\begin{array}{c}\text { Erwinia } \\
\text { carotovora }\end{array}$ & $\begin{array}{l}\text { Klebsiella } \\
\text { oxytoca }\end{array}$ & $\begin{array}{c}\text { Pseudomonas } \\
\text { aeruginosa }\end{array}$ \\
\hline \multicolumn{10}{|c|}{ Amula } \\
\hline 1 & + & - & - & - & + & - & - & + & - \\
\hline 2 & + & + & - & - & + & - & - & - & + \\
\hline 3 & + & - & + & - & + & - & - & + & - \\
\hline 4 & + & - & + & + & + & - & - & - & + \\
\hline 5 & + & - & + & + & + & - & - & - & + \\
\hline Incidence Ratio & $5 / 5$ & $1 / 5$ & $3 / 5$ & $2 / 5$ & $5 / 5$ & $0 / 5$ & $0 / 5$ & $2 / 5$ & $3 / 5$ \\
\hline \multicolumn{10}{|c|}{ Ogoja } \\
\hline 1 & + & - & - & + & - & + & - & - & + \\
\hline 2 & + & + & + & + & + & + & - & - & - \\
\hline 3 & + & - & - & + & + & + & - & - & + \\
\hline 4 & + & + & - & - & - & + & - & + & + \\
\hline 5 & + & - & + & + & + & - & + & + & - \\
\hline Incidence Ratio & $5 / 5$ & $2 / 5$ & $2 / 5$ & $4 / 5$ & $3 / 5$ & $4 / 5$ & $1 / 5$ & $2 / 5$ & $3 / 5$ \\
\hline \multicolumn{10}{|c|}{ Hembamkwase } \\
\hline 1 & + & - & + & + & + & - & + & - & - \\
\hline 2 & + & - & - & + & - & - & - & + & - \\
\hline 3 & + & - & + & - & + & - & + & - & + \\
\hline 4 & + & + & - & + & + & + & - & - & - \\
\hline 5 & + & - & + & - & + & - & - & - & + \\
\hline Incidence Ratio & $5 / 5$ & $1 / 5$ & $3 / 5$ & $3 / 5$ & $4 / 5$ & $1 / 5$ & $2 / 5$ & $1 / 5$ & $2 / 5$ \\
\hline \multicolumn{10}{|c|}{ Gbongu } \\
\hline 1 & + & - & - & + & - & + & - & - & + \\
\hline 2 & + & + & + & + & + & + & - & - & - \\
\hline 3 & + & - & - & + & + & + & - & - & + \\
\hline 4 & + & + & - & - & - & + & - & + & + \\
\hline 5 & + & - & + & + & + & - & + & + & - \\
\hline Incidence Ratio & $5 / 5$ & $2 / 5$ & $2 / 5$ & $4 / 5$ & $3 / 5$ & $4 / 5$ & $1 / 5$ & $2 / 5$ & $3 / 5$ \\
\hline
\end{tabular}

Key: 1 = Ukum local government area; 2 = Katsina Ala local government area; 3 = Logo local government area; 4 = Vandeikya local government area; 5 = Guma local government area; + = Present; - = Absent.

\section{Table 3. Biochemical test.}

\begin{tabular}{ccccc}
\hline & \multicolumn{5}{c}{ Micro-Organisms } \\
\cline { 2 - 5 } TEST(S) & Serratia marcescens & Erwinia carotovora & Klebsiella oxytoca & Pseudomonas aeruginosa \\
\hline Gram Staiming Reaction & - & - & - & - \\
Catalase & + & + & - & + \\
Oxidase & - & - & - & + \\
Citerate Utilisation & + & - & + & - \\
Gas & - & - & - & - \\
$\mathrm{H}_{2} \mathrm{~S}$ (Hydrogen Sulphide) & - & - & - & + \\
Motility & + & - & - & Blue \\
Pigment & Red & 7.36 & - & + \\
$\mathrm{PH}$ (Nutrient Broth Medium) & 7.49 & - & - & + \\
Acid & + & &
\end{tabular}

Key: + = Positive Reaction; - = Negative Reaction. 
Table 4. Determination of optimal growth temperature of the isolates/radial growth diameter.

\begin{tabular}{ccccccccc}
\hline \multirow{2}{*}{$\begin{array}{c}\text { Temperature } \\
\left({ }^{\circ} \mathrm{C}\right)\end{array}$} & $\begin{array}{c}\text { Fspergillus } \\
\text { niger }\end{array}$ & $\begin{array}{c}\text { Rhizopus } \\
\text { stolonifera }\end{array}$ & $\begin{array}{c}\text { Botryodiplodia } \\
\text { theobromae }\end{array}$ & $\begin{array}{c}\text { Fusarium } \\
\text { oxysporum }\end{array}$ & $\begin{array}{c}\text { Serratia } \\
\text { marcescens }\end{array}$ & $\begin{array}{c}\text { Erwinia } \\
\text { carotovora }\end{array}$ & $\begin{array}{c}\text { Klebsiella } \\
\text { oxytoca }\end{array}$ & $\begin{array}{c}\text { Pseudomonas } \\
\text { aeruginosa }\end{array}$ \\
\hline 28 & 5.6 & 5.4 & 4.4 & 3.2 & 2.5 & 2.5 & 2.5 & 4.0 \\
30 & 6.0 & 6.4 & 5.8 & 3.6 & 2.5 & 2.5 & 2.5 & 4.0 \\
32 & 6.4 & 6.6 & 6.2 & 4.6 & 3.0 & 3.0 & 4.0 & 3.0 \\
34 & 6.8 & 7.2 & 6.4 & 5.0 & 3.0 & 3.0 & 4.0 & 3.0 \\
36 & 7.2 & 7.6 & 6.8 & 5.2 & 3.0 & 3.0 & 3.0 & 3.0 \\
38 & 7.4 & 7.8 & 7.2 & 5.4 & 3.0 & 3.0 & 3.0 & 3.0 \\
40 & 4.8 & 6.8 & 4.8 & 5.2 & 1.0 & 1.0 & 1.0 & 2.0 \\
42 & 3.6 & 6.6 & 4.4 & 5.0 & - & - & - & 1.0 \\
\hline
\end{tabular}

Key: - = No growth.

Table 5. Pathogencity test-rot measurement.

\begin{tabular}{|c|c|c|c|c|c|c|c|c|}
\hline \multirow{2}{*}{ Microorganisms } & \multicolumn{2}{|c|}{ Amula } & \multicolumn{2}{|c|}{ Ogoja } & \multicolumn{2}{|c|}{ Hembamkwase } & \multicolumn{2}{|c|}{ Gbongo } \\
\hline & Width (cm) & Depth (cm) & Width (cm) & Depth (cm) & Width (cm) & Depth (cm) & Width $(\mathrm{cm})$ & Depth (cm) \\
\hline Aspergillus niger & 2.0 & 3.0 & 2.0 & 3.0 & 1.5 & 3.0 & 2.0 & 3.5 \\
\hline Rhizopus stolonifera & 1.0 & 2.8 & 1.0 & 2.5 & 1.0 & 3.0 & 2.5 & 4.0 \\
\hline $\begin{array}{l}\text { Botryodiplodia } \\
\text { theobromae }\end{array}$ & 1.0 & 2.0 & 1.5 & 3.0 & 1.0 & 2.5 & 1.0 & 2.0 \\
\hline Fusarium oxysporum & 1.5 & 3.0 & 1.0 & 2.5 & 1.0 & 2.0 & 2.0 & 2.0 \\
\hline Penicillium marnessei & - & - & - & - & - & - & - & - \\
\hline Serratia marcescens & 1.0 & 2.0 & 1.3 & 3.0 & 1.2 & 3.0 & 1.0 & 3.0 \\
\hline Erwinia carotovora & 1.0 & 5.0 & 1.0 & 2.8 & 1.7 & 3.5 & 1.0 & 2.0 \\
\hline Klebsiella oxytoca & 1.3 & 3.5 & 1.7 & 2.7 & 1.5 & 2.3 & 1.0 & $2 . .0$ \\
\hline $\begin{array}{l}\text { Pseudomonas } \\
\text { aeruginosa }\end{array}$ & 1.0 & 2.5 & 1.2 & 3.0 & 1.5 & 3.5 & 2.0 & 3.5 \\
\hline All Fungi & 1.7 & 2.3 & 2.5 & 3.0 & 2.5 & 3.8 & 2.0 & 3.5 \\
\hline All Bacteria & 1.5 & 3.5 & 2.5 & 3.5 & 2.0 & 3.5 & 2.0 & 3.8 \\
\hline All Fungi \& Bacteria & 2.5 & 4.0 & 2.3 & 3.2 & 3.5 & 3.5 & 3.0 & 3.5 \\
\hline
\end{tabular}

Key: - = No pure isolate of Penicillium marnessei was obtained for the test due to tight growth with Aspergillus niger.

Serratia marcescens showed resistance to extracts of Terminalia catapa and Passiflora edulis in all the concentrations. Daniella oliveri recorded mild sensitivity at undiluted concentration (100\%) only. Ceiba pentandra extract showed moderate activity at undiluted concentration, mild activity at $10^{-1}$ and no activity at $10^{-2}$ concentrations. Jatropha tanjorensis recorded mild activity at $100 \%$ and no activity in the dilutions (Table 6).

Erwinia carotovora showed high sensitivity with extracts of Terminalia catapa in all the concentrations. Passiflora edulis recorded good sensitivity at $100 \%$ concentration, moderate sensitivity at $10^{-1}$ concentration and mild sensitivity at $10^{-2}$. Daniella oliveri recorded no activity in all the concentrations. Ceiba pentandra recorded mild sensitivity in all the concentrations. Jatropha tanjorensis recorded good sensitivity at undiluted concentration, moderate sensitivity at $10^{-1}$ and mild sensitivity at $10^{-2}$ concentrations (Table 6).

Klebsiella oxytoca showed mild sensitivity with extracts of Terminalia catapa, Passiflora edulis, and Daniella oliveri in all the concentrations. Ceiba pentandra recorded moderate sensitivity at undiluted concentration, 
Table 6. Sensitivity test (minimum inhibitory concentration).

\begin{tabular}{|c|c|c|c|c|c|c|}
\hline \multirow{3}{*}{ Plant } & \multicolumn{3}{|c|}{ Fungi/Extract Concentrations } & \multicolumn{3}{|c|}{ Bacteria/Extract Concentrations } \\
\hline & \multicolumn{3}{|c|}{ Aspergillus niger } & \multicolumn{3}{|c|}{ Serratia marcescens } \\
\hline & $100 \%$ & $10^{-1}$ & $10^{-2}$ & $100 \%$ & $10^{-1}$ & $10^{-2}$ \\
\hline Terminalia catapa & + & - & - & - & - & - \\
\hline Passiflora edulis & +++ & +++ & + & - & - & - \\
\hline Daniella oliveri & + & - & - & + & - & - \\
\hline Ceiba pentandra & - & + & + & ++ & + & - \\
\hline \multirow[t]{2}{*}{ Jatropha tanjorensis } & + & + & + & + & - & - \\
\hline & \multicolumn{3}{|c|}{ Rhizopus stolonifera } & \multicolumn{3}{|c|}{ Erwinia carotovora } \\
\hline Terminalia catapa & ++ & + & + & ++++ & +++++ & +++ \\
\hline Passiflora edulis & ++++ & ++++ & +++ & +++ & ++ & + \\
\hline Daniella oliveri & - & - & - & - & - & - \\
\hline Ceiba pentandra & - & - & - & + & + & + \\
\hline \multirow[t]{2}{*}{ Jatropha tanjorensis } & +++ & + & - & +++ & ++ & ++ \\
\hline & \multicolumn{3}{|c|}{ Fusarium oxysporum } & \multicolumn{3}{|c|}{ Klebsiella oxytoca } \\
\hline Terminalia catapa & + & + & + & + & + & + \\
\hline Passiflora edulis & +++ & ++ & ++ & + & + & + \\
\hline Daniella oliveri & + & + & ++ & + & + & + \\
\hline Ceiba pentandra & +++ & +++ & + & ++ & + & + \\
\hline \multirow[t]{2}{*}{ Jatropha tanjorensis } & +++ & ++ & + & ++++ & ++ & + \\
\hline & \multicolumn{3}{|c|}{ Botryodiplodia theobromae } & \multicolumn{3}{|c|}{ Pseudomonas aeruginosa } \\
\hline Terminalia catapa & - & - & - & +++ & ++ & + \\
\hline Passiflora edulis & +++ & +++ & +++ & + & + & + \\
\hline Daniella oliveri & + & - & - & ++ & ++ & + \\
\hline Ceiba pentandra & - & - & - & +++ & +++ & ++ \\
\hline Jatropha tanjorensis & - & - & - & ++++ & ++++ & ++++ \\
\hline
\end{tabular}

Key: $100 \%=$ undiluted plant extract; +++++, ++++ = high sensitivity or activity; +++ = good sensitivity or activity; ++ = moderate sensitivity or activity; + = mild sensitivity or activity; $-=$ no sensitivity or activity.

mild sensitivity at $10^{-1}$ and $10^{-2}$ concentrations. Jotropha tanjorensis recorded high sensitivity at $100 \%$ concentration, moderate sensitivity at $10^{-1}$ concentration and mild sensitivity at $10^{-2}$ concentration (Table 6).

Pseudomonas aeruginosa showed good sensitivity with extract of Terminalia catapa at undiluted concentration, moderate sensitivity at $10^{-1}$ concentration and mild sensitivity at $10^{-2}$ concentration. Passiflora edulis recorded mild sensitivity in all the concentrations. Daniella oliveri recorded moderate sensitivity at undiluted and $10^{-1}$ concentrations and mild sensitivity at $10^{-2}$ concentration. Ceiba pentandra recorded good sensitivity at undiluted and $10^{-1}$ concentrations, moderate sensitivity at $10^{-2}$ concentration. Jatropha tanjorensis showed high sensitivity in all the concentrations (Table 6).

\subsection{Discussion}

This study reveals the types of fungi and bacteria species associated with the white yam tuber rot in some parts of Benue State, Nigeria.

The microorganisms isolated were five fungal species, Aspergillus niger, Rhizopus stolonifera, Botryodiplo- 
dia theobromae, Fusarium oxysporum and Penicillium marnessei and four bacteria species, Serratia marcesens, Erwinia carotovora, Klebsiella oxytoca and Pseudomonas aeruginosa. The result obtained from fungal rot organisms isolated is in agreement with earlier results reported by [2] [6] [7] [15] [26] [27]. Brown hard rot was recorded with the fungi Aspergillus and Fusarium in all yam varieties, and the bacteria Pseudomonas in Ogojo yam variety. Soft rot was recorded with the fungi Rhizopus and Botryodiplodia and with all the bacteria isolated. Wet rot was recorded with the bacteria Erwinia carotovora and in the associative growth of all bacteria; all bacteria and all fungi. Also, associative growth of all fungi and all bacteria recorded only soft rot. The findings are in agreement with earlier reports by [12]. The fungi Aspergillus niger and the bacteria Pseudomonas isolated are known to be human pathogenic or opportunistic human pathogenic organisms. The bacteria Klebsiella oxytoca isolated is reported to be pathogenic in plants only though other species of Klebsiella are known to be of human pathogens. However yams are well sterilized by cooking before eating so the danger is evaded [28].

Optimal growth temperature studies showed that both fungi and bacteria have $38^{\circ} \mathrm{C}$ as optimum growth temperature. The temperature of $28^{\circ} \mathrm{C}$ was not too favourable for all microorganisms. This calls for cold storage studies investigation for the yam tubers [4].

Result of the Pathogenic test revealed that the organisms isolated were responsible for the yam rot and it ranged from dry hard rot, soft rot and watery rot. Also collectively as all fungi, all bacteria or all fungi and all bacteria combined produce higher degree of rot than when the organisms were introduced individually. Microorganisms that were not isolated in yam from some local government areas were observed to cause rot when inoculated. This shows that the environment under which the yams were harvested in those local government areas was not conducive for certain microbial growth.

The result of antimicrobial test conducted on the isolated organisms on culture media plates using plant extracts reveal that all the plants used had both antifungal and antibacterial effects and were able to inhibit the growth of at least two or more fungi (Passiflora edulis extract inhibited all) or bacteria (Terminalia catapa, Ceiba pentandra and Jatropha tanjorensis were able to inhibit three bacteria) isolated respectively. The organism Serratia marcescens was resistant to the extracts, showing only mild sensitivity with Daniella oliveri, Ceiba pentandra, Jatropha tanjorensis extracts at undiluted concentrations only. This finding is in agreement with earlier report by [29] [30].

The plant kingdom still holds many species of plants of medicinal values which are yet to be discovered [31]. This study calls for more research on the screening of more plants for their antimicrobial activity against yam tuber rot organisms, to come up with possible means of utilising them for better yam tuber storage for longer shelf life, economic enhancement and all year round availability.

There is need for more work on the antimicrobial activity of plants in consultation with the natives who have been using these for treatment of infections of plants and humans. In this research we declined to use methanol or ethanol for the extraction of antimicrobials from plants but followed the aqueous extraction used by the natives, even though methanol and ethanol extract more antimicrobial from plants than water [32]. Indeed it is observed that aqueous extract from Passiflora edulis, Ceiba pentandra and Jatropha tanjorensis were able to inhibit all the fungi completely.

\section{Conclusion}

Microoganisms: Aspergillus niger, Rhizopus stolonifera, Botryodiplodia theobromae, Fusarium oxysporium, Penicillium marnessei, Serratia marcescens, Erwinia carotovora, Klebsiella oxytoca and Pseudomonas aeruginosa isolated from rotten yam tubers from the study areas were inhibited fully or partially by the plants cold aqueous extracts under study. Further research on this project can provide solutions to post harvest losses which are in easy reach to farmers and their competence. There is need to study the organic compounds produced during yam rot to ascertain whether they are infectious to human beings or otherwise. We need to know how extracellular enzymes of these organisms break down carbohydrate polymers of the tubers.

\section{Acknowledgements}

We wish to thank the management of Benue State University for the facilities and finances made available to us to carry out this research. We also appreciate the famers in the various local governments where the samples were obtained. Their useful discussions did not only encourage us but was helpful in carrying out the work. The cooperation of the staff of Biology and Chemistry Departments of Benue State University is highly appreciated. 


\section{References}

[1] Ezeibekwe, I.O. and Ibe, A.E. (2010) Fungal Organisms Associated with Yam (Dioscorea rotundata, poir) Rot at Owerri, Imo State of Nigeria. Journal of Molecular Genetics, 2, 1-5. http://dx.doi.org/10.3923/jmolgene.2010.1.5

[2] Taiga, A. (2012) Differential Rate of Dry Rot in Dioscorea rotundata (White Yam) along the Tuber Length Due to Rot Causing Fungi. Advances in Microbiology, 2, 452-455. http://dx.doi.org/10.4236/aim.2012.24058

[3] Akanji, B.O., Akpokodje, G. and Ogundele, O.O. (2003) Labour Use Pattern on Farms. NISER, Annual Survey of Crop Production Condition in Nigeria, 34-46.

[4] Osunde, Z.D. (2008) Minimizing Postharvest Losses in Yam (Dioscorea spp.): Treatment and Techniques. International Union of Food Science and Technology, Raleigh, 1-12.

[5] Akangbe, J.A., Oloruntoba, O.O., Ayanda, I.F. and Komolafe, S.E. (2012) An Analysis of Yam Storage Strategy to Promote Food Security in Asa Local Government Area of Kwara State, Nigeria. Ethiopian Journal of Environmental Studies and Management, 5. http://dx.doi.org/10.4314/ejesm.v5i4.S15

[6] Ajayi, A.O. and Olorundare, S.D. (2014) Bacterial and Fungi Species Associated with Yam (Dioscorea rotundata) Rot at Akanugba-Akoko, Ondo Staste, Nigeria. Applied Science Research Journal, 2, 12-28.

[7] Ray, R.C., Nedunzhiyan, M. and Balagopalan, C. (2000) Microorganisms Associated with Postharvest Spoilage of Yams. Annals of Tropical Research, Philipines, 22, 31-40

[8] Gosh, S.P., Ramanujam, T., Jos, J.S., Moorthy, S.N. and Nair, R.G. (1999) Tuber Crops. Oxford \& IBH Publishing Co. Pvt. Ltd., New Delhi.

[9] Noon, O. (1978) Fungus Diseases of Plants and Their Treatments. Agricultural Research, 11, 50-55.

[10] Onwueme, I.C. (1978) The Tropical Tuber Crops-Yams, Cassava, Sweet potato and Cocoyams. John Wiley and Sons, Chichester, 3-97.

[11] Amusa, N.A. (2001) Fungi Associated with Yam Chips in Storage and the Effect on Its Food Value. Moor Journal of Agricultural Research, 2, 35-39.

[12] Amusa, N.A. and Baiyewa, R.A. (1999) Storage and Market Disease of Yam Tubers in Southwestern Nigeria. Ogun Journal of Agriculture Research, 11, 211-225.

[13] Morse, S., Acholo, M., McNamara, N. and Oliver R. (2000) Control of Storage Insects as a Means of Limiting Yam Tuber Fungal Rots. Journal of Stored Products Research, 36, 37-44. http://dx.doi.org/10.1016/S0022-474X(99)00025-9

[14] Green, K.R., Sangoyomi, A.T. and Amusa N.A. (1995) The Importance of Rhizoctonia solani as a Pathogen of Yam (Dioscorea spp.) in Nigeria. Proceedings of the 6th Symposium of International Society for Roots and Tuber Crops. African Branch, Lilongwe, 22-28 October 1995, 412-418.

[15] Okigbo, R.N. and Emeka, A.N. (2010) Biological Control of Rot-Inducing Fungi of Water Yam (Dioscorea alata) with Trichoderma harzianum, Pseudomonas syringae, and Pseudomonas chlororaphis. Journal of Stored Products and Postharvest Research, 1, 18-23.

[16] Cheesbrough, M. (2000) District Laboratory Practice in Tropical Counties. Low Price Edition, Cambridge University Press, Cambridge, UK, 62-70.

[17] Nair, R. and Chanda, S. (2008) Antimicrobial Activity of Terminalia catappa, Manilkara zapota and Piper betel Leaf Extract. Indian Journal of Parmaceutical Sciences, 70, 390-393.

[18] Muhammad, A. and Mudi, S.Y. (2011) Phytochemical Screening and Antimicrobial Activity of Terminalia catappa, Leaf Extracts. Nigerian Society for Experimental Biology, 23, 35-39.

[19] Shiamala, D.R., Japar, S.B. and Muta, H.Z. (2014) Assessment of Total Phenolic, Antioxidant and Antibacterial Activitives of Passiflora Species. The Scientific World Journal, 2014, Article ID: 167309. http://dx.doi.org/10.1155/2014/167309

[20] Ravi, K.C., Sirisha, N. and Raghava, R.T. (2012) Physico-Chemical Characterization and Antimicrobial Activity of Ceiba pentandra Seed and Oil. Alternative Medicine, 2, e9. http://dx.doi.org/10.4081/ams.2012.e9

[21] Sekaran, R. (1998) Antimicrobial Action of the Leaf Extract of Jatropha tanjorensis (E \& R). Ancient Science of Life, 18, 50-51.

[22] Krieg, N. (1984) Bergeys Manual of Systematic Bacteriology. Williams and Wilkins, Boltimore, Vol. 1, 21-38.

[23] Barnett, H.L. and Hunter, B.B. (1972) Illustrated General of Imperfect Fungi. 3rd Edition, Burgess Publications Co., Minneapolis, $241 \mathrm{p}$.

[24] Banso, A. and Sani, A. (2003) Antibacterial Effect of Leaf Etract of Ricinus communis. African Scientist, 4, $129-133$. http://Klobexpublishers.com 
[25] Abubacker, M.N., Ramanathan, R. and Kumar, T.S. (2008) Invitro Anti-Fungal Activity of Cassia alata Linn. Flower Extract. Natural Product Radiance, 7, 6-9.

[26] Okigbo, R.N. (2005) Biological Control of Postharvest Fungal Rot of Yam (Dioscorea spp.) with Bacillus subtilis. Mycopathologia, 159, 307-314. http://dx.doi.org/10.1007/s11046-004-2454-8

[27] Ogeraku, A.O. and Usman, H.O. (2008) Storage Rot of Some Yams (Dioscorea spp) in Keffi and Environs, Nasarawa State, Nigeria. Production Agriculture Technology, 4, 22-27.

[28] Gajera, H.P. and Vakharir, D.N. (2012) Production of Lytic Enzymes. Brazilian Journal of Microbiology, 43, 43-52.

[29] Devi, K., Karthikai, G. Thirumaran, G., Arumugam, R. and Anantharaman, P. (2009) Antibacterial Activity of Selected Medical Plants from Parangipettai Coastal Region, Southeast Coast of India. World Applied Sciences Journal, 7, 1212-1215.

[30] Ali, E., Almagboul, A., Khogali, S. and Gergeir, U. (2012) Antimicrobial Activity of Cannabis sativa L. Chinese Medicine, 3, 61-64. http://dx.doi.org/10.4236/cm.2012.31010

[31] Odebiji, O. and Sofowara, E.A. (1979) Antimicrobial Alkaloids from a Nigerian Chewing Stick (Fagara zanthoxyloides). Planta Medica, 36, 204-207. http://dx.doi.org/10.1055/s-0028-1097271

[32] Cowan, M.M. (1999) Plant Products as Antimicrobial Agents. Clinical Microbiology Reviews, 12, 564-582. 